\title{
Bedlington Terrier
}

National Cancer Institute

\section{Source}

National Cancer Institute. Bedlington Terrier. NCI Thesaurus. Code C53713.

The Bedlington Terrier has a pear-shaped head, arched back and a thick, curly double coat that comes in a blue, liver, or sandy color. It resembles a lamb. Height: 15-17 inches (38-43cm) Weight: $18-23$ pounds (8-10 kg.) 